IJOTL TL, Vol. 4, No. 3, September 2019

p ISSN: 2502 2326; e ISSN: 2502 8278

Https://soloclcs.org; Email: ijolt1@gmail.com

Center of Language and Cultural Studies, Surakarta, Indonesia

Bazzaz, Edalati Vahid; Niami, Maryam \& Mohammadi, Sharbanoo . 2019. The Impact of Direct and

Indirect Feedback on Idiom Translating Skills of Iranian EFL College Students. IJOTL TL (2019), 4(3): 129 144. DOI: 10.30957/ijotl-tl.v4i3.605.

\title{
The Impact of Direct and Indirect Feedback on Idiom Translating Skill of Iranian EFL College Students
}

Vahid Edalati Bazzaz

\author{
University of Applied Science and Technology, Iranian Academic Center for \\ Education, Culture and Research (ACECR), Khorasan Razavi Branch, Mashhad, \\ Iran, \\ edalati_vahid@yahoo.com \\ Tell: 00989155208079
}

\author{
Maryam Niami* \\ Islamic Azad University (IAU), Parand Branch, \\ maryamniami@gmail.com \\ *Corresponding author; Tel: 00989125473094 \\ Shahrbanoo Mohammadi \\ Islamic Azad University (IAU), Parand Branch, \\ banoomohammadi89@gmail.com
}

Tell: 00989127292448

\begin{abstract}
This study examines the effectiveness and efficacy of teachers direct vs. indirect feedback on students' idiom translating skill. To achieve this purpose, 23 Iranian university students from two intact classes were randomly assigned to two experimental groups: direct feedback group in which the teacher located and gave the correct translation of idiom and indirect feedback group in which the teacher only noted the number of wrong translations of idioms. The study lasted 10 weeks in the course of which the participants had to translate a short text from "Idioms and Metaphorical Expressions in Translation" by "Ghaffar Tajalli". The study included a pre-test, a treatment for experimental groups, and a post-test to see whether or not the treatment had been effective. The statistical analyses indicated the effectiveness of direct feedback in accurate use of translation of idioms. Therefore, the results can provide some useful insights in translating courses, syllabus design, and translator training courses.
\end{abstract}

Key words: direct feedback, indirect feedback, idioms, EFL learners

\section{INTRODUCTION}

Translation study is a new discipline in Iran, so educators and researchers attempt to find out different factors which influence on translation in order to hone the 
IJOTL TL, Vol. 4, No. 3, September 2019

p ISSN: 2502 2326; e ISSN: 2502 8278

Https://soloclcs.org; Email: ijolt1@gmail.com

Center of Language and Cultural Studies, Surakarta, Indonesia

Bazzaz, Edalati Vahid; Niami, Maryam \& Mohammadi, Sharbanoo . 2019. The Impact of Direct and

Indirect Feedback on Idiom Translating Skills of Iranian EFL College Students.

IJOTL TL (2019), 4(3): 129 144. DOI: 10.30957/ijotl-tl.v4i3.605.

quality of translation. As English language is very rich in the use of idiomatic expressions, appropriate translation of idioms and expression can be considered as a major element affecting the quality of translation. In most English as Foreign Language (EFL) contexts like Iran, translators are not proficient enough in translation of idioms, so, translation instructors make several attempts in order to assist new translators to provide accurate translation. One of such attempts is providing feedback. Shore (2001) acknowledges that providing feedback for learners' translation works should serve two objectives: 1) to alert the instructor to present problems in the students' assignments, 2) to alert learners to possible errors and ways of honing their translations'. Furthermore, according to Séguinot (1991) Feedback is supposed to be a source of support which enables novice translators to progress.

During the last few decades, considerable research effort was expended on the effect of teacher-written feedback (TWF) on Second Language (L2) writing as an integral part of the process oriented instructional approach to writing. Applying the effectiveness of the TWF to translation instruction seems to be valid although it is still inconclusive. On that account, this study endeavors to examine to what extend giving the suitable feedback to translators' homework will develop the quality of their translations in idiomatic expressions. It is expected that the results of the research would directly improve the development of learners' translation quality and also provide more insight for instructors into different kinds of feedback to develop the skill of idiom translation.

\section{REVIEW OF LITERATURE}

\subsection{Definition of Idiom}

Idioms play a significant and integral part of any written and spoken texts. Idioms are seen as a colorful and verbal image that put verve and life to both speech and writing (as cited in Aldahesh, 2013, p. 24). Idioms are defined in the Collins English Dictionary (2006) as" an expression such as a simile, in which words do not have their literal meaning, but are categorized as multi- word expressions that act in the text as units". Longman Idioms Dictionary (1998) defines them as" a sequence of words which has a different meaning as a group from the meaning it would have if you understood each word separately. For instance, the expression "kick the bucket" has an idiomatic meaning (to die) that has nothing to do with the meaning of kick or bucket. There are number of ways in which idioms are categorized by many researchers (Makkai, 1972).

\subsection{Translating Idioms}

Generally, translation is not a simple task and translating idioms, in particular, makes it rather more demanding task. Idioms are types of multi-word expressions which are often appeared in various texts and used in all languages (Cook, Fazly\& Stevenson, 2008). However, an appropriate translation of idioms has been overlooked by researchers in the area of translation studies. In order to translate idioms, some steps must be taken into consideration before choosing the most suitable meaning for idioms. First, the translator must recognize idioms and spot them in the text and then he tries to 
IJOTL TL, Vol. 4, No. 3, September 2019

p ISSN: 2502 2326; e ISSN: 2502 8278

Https://soloclcs.org; Email: ijolt1@gmail.com

Center of Language and Cultural Studies, Surakarta, Indonesia

Bazzaz, Edalati Vahid; Niami, Maryam \& Mohammadi, Sharbanoo . 2019. The Impact of Direct and

Indirect Feedback on Idiom Translating Skills of Iranian EFL College Students.

IJOTL TL (2019), 4(3): 129 144. DOI: 10.30957/ijotl-tl.v4i3.605.

understand and interpret the idioms accurately. As Larson (1984, p. 143) acknowledges that "the translator must first be sure of the meaning of the idiom and then look for the natural equivalent way to express the meaning of the idiom as a whole". Baker (2011) accentuates that a professional translator must be precise, sensitive, and aware of rhetorical hints of the language. Baker adds that in translating a text, it is essential to consider not only the meaning of idioms but also their forms. Since it is not possible to literally translate an idiom, its context as well as its equivalence must be noted. However, when it comes to translation of idioms, the translators translate the idioms literally which make their translation inaccurate and unnatural. Baker (1992) states that:" Idioms are frozen patterns of languages which allow little or no variation in form and often carry meanings which cannot be deduced from their individual components" (p.63).

\subsection{The Importance of Constructive Feedback in Translation}

Teachers must accept the fact that translating from one language into another language contains errors and these errors are related to linguistic, situational and cultural features. Students come to class both to improve their language proficiency and become more confident in their translation abilities. So, instructors should provide learners with proper language input, translation experience, and feedback to fulfill their goals. Overt classroom instruction is only one factor of teaching process and providing students with feedback on their translations is another factor.

In an early paper, Dollerup (1994) distinguishes three components of constructive feedback: these consist of teacher's written commentary on a task or feedback form with a grade, evaluating the strengths and weaknesses with each translator and finally oral discussion. This article tries to apply the first approach which is named as corrective feedback (CF) to students' translation. CF has been remained the most contentious issue in L2. Shreve (2002, p.29) claims that "assessment of areas for improvement could be greatly facilitated by feedback from others involved in the translation activity".

The ongoing debate over the effectiveness of CF can be traced back to the debate between Truscott and Ferris in the mid to late 1990s. According to the most extreme view, such as Truscott $(1996 ; 2007)$, error correction plays no facilitative role in improving learners' acquisition. He mentions harmful effect of correction, including decreasing fluency in writing, increasing anxiety, and lowering confidence Furthermore, other researchers including Polio, Fleck and Leder (1998); Hendrickson (1978); Leki (1990); Sheppard (1992) concluded that feedback might not contribute to language development. Al-Jarrah (2016) by moving a step further claims that although provision of feedback decreases the amount of confusion that learners may experience, it doesn't develop their long-term learning. Ferris (1999, 2004), nevertheless, argues error correction is essential and useful due to the fact that learners prefer, require and rely on teacher's feedback. The aforementioned investigations are from the areas of writing research and educational psychology, but are applicable to many other fields of text production. One such area is translation studies as Shikano (2015) strongly asserts that TWF can effectively be applied to translation process, due to the fact that developing 
IJOTL TL, Vol. 4, No. 3, September 2019

p ISSN: 2502 2326; e ISSN: 2502 8278

Https://soloclcs.org; Email: ijolt1@,gmail.com

Center of Language and Cultural Studies, Surakarta, Indonesia

Bazzaz, Edalati Vahid; Niami, Maryam \& Mohammadi, Sharbanoo . 2019. The Impact of Direct and

Indirect Feedback on Idiom Translating Skills of Iranian EFL College Students.

IJOTL TL (2019), 4(3): 129 144. DOI: 10.30957/ijotl-tl.v4i3.605.

translation competence is as complex a process as writing, or even more and also because translation needs linguistic competence in the given two languages simultaneously.

\subsection{Direct vs. Indirect Feedback}

In proposing feedback process, Van Steendam, Rijlaarsdam, Van den Bergh, Sercu and Lies (2014) propose three conventional approaches to translation: detection (of errors in the learner's text), diagnosis (preferably with an explanation of the problem) and correction (in the form of a suggested solution to aid the learner). Taxonomies of feedback types vary across investigators. To do so, we should like to add a fourth process element: Direct feedback (DF) and Indirect Feedback (IF).The dichotomy of direct versus indirect type of feedback has motivated the researchers to investigate the priority of one over another (Bates, Lane, \& Lange, 1993; Ferris, 1995; Ferris \& Hedgcock, 1998; Hendrickson, 1978, 1980; Lalande, 1982; Walz, 1982). DF, as the name suggests, the correct form of the inaccurate form is provided by the instructors (Lalande, 1982; Robb, Ross, \& Shortreed, 1986). Of those who prioritize direct written CF, we can name Farrokhi and Sattarpour (2012), Bitchener, Young, and Cameron (2005), Chandler (2003), Ferris and Roberts (2001), Komura (1999), Van Beuningen, De Jong, and Kuiken, $(2008,2012)$. Lee (2008) has simply stated that DF can be suitable for lower-level learners or in a condition that errors are untreatable and not susceptible to self-correction such as a sentence structure and a word choice.

The author adds that teachers utilize DF when they intend to direct learner attention to error patterns that require student correction. In contrast, in IF, the teacher indicates that there is an error but $\mathrm{s} /$ he does not actually correct it. IF involves using an error code, underlying or circling the error but without providing the correct form (Bitchener, 2008; Ellis, 2009; Ferris \&Robberts, 2001; Robbet al., 1986). Several researchers discovered that IF resulted in either greater or similar levels of accuracy over time (Lalande, 1982; Robb et al., 1986). Lalande (1982) found evidence that IF could assist learners to engage in reflective thinking, which could likely lead to longterm learning (Ferris \& Roberts, 2001). Moreover, many researchers believe IF show the most potential for assisting students in developing their L2 proficiency and metalinguistic knowledge (Ferris \& Hedgcock, 2005). In the literature of language education, there seems to be no consensus concerning priority of DF over IF and vice versa. Several reasons may describe this inconclusive finding, including the type of error (Ferris, 2006), students' aptitude (Sheen, 2007), learners' proficiency levels (e.g., Sheen, Wright \& Moldawa, 2009), and finally, affective factors like learners 'attitude and prior educational experiences (e.g., Storch \& Wigglesworth, 2010a, 2010b).

Although majority of investigations on correction feedback were carried out in the area of writing accuracy, spelling, vocabulary, and so on, the present article tries to apply feedback in the area of translation study. Hence, the aim of this study is to investigate the Impact of direct and indirect feedback on idiom translating skill of Iranian EFL college students.

\section{METHODS}


IJOTL TL, Vol. 4, No. 3, September 2019

p ISSN: 2502 2326; e ISSN: 2502 8278

Https://soloclcs.org; Email: ijolt1@gmail.com

Center of Language and Cultural Studies, Surakarta, Indonesia

Bazzaz, Edalati Vahid; Niami, Maryam \& Mohammadi, Sharbanoo . 2019. The Impact of Direct and

Indirect Feedback on Idiom Translating Skills of Iranian EFL College Students.

IJOTL TL (2019), 4(3): 129 144. DOI: 10.30957/ijotl-tl.v4i3.605.

\subsection{Participants}

The study was conducted in the Audio-Visual Department of Institute of Applied Science and Technology in Iran. The sample came from two intact classes of translation study students who had completed 2 years of translation study. They were B.A. students who had enrolled in theory of translation course as the requirement of the university curriculum. The participants' age ranged from 19 to 25 with an average of 21 and $56(85 \%)$ of them were female and $11(15 \%)$ were male. All learners were Iranian nationals with Persian as their first language. The class sizes ranged from 19 to 25 . Out of the total of 35 students, 25 students completed consent forms and participated in the study. Accordingly, two groups (intact classes) were randomly formed: DF group ( $\mathrm{n}=$ 11) and IF group $(n=12)$. They were told that the tasks and tests were for purposes of research and that the results of the study would not affect their grades.

The teacher was one of the researchers. He was an experienced non-native speaking teacher of English as a foreign language and possessed a master degree in English language teaching.

\subsection{Research Questions and Hypothesis}

To fulfill the above mentioned aims, the following research questions were posed:

1) Does DF have any significant impact on translating skills of Iranian EFL college students?

2) Does IF have any significant impact on translating skills of Iranian EFL college students?

The following research hypotheses were formulated on the basis of research questions:

H0 ${ }^{1}$ : DF does not have any significant impact on translating skills of Iranian EFL college students.

$\mathrm{HO}^{2}$ : IF does not have any significant impact on translating skills of Iranian EFL college students.

\subsection{Treatment Materials}

In order to answer the research questions raised in the study, 10 English texts from the books "Idioms and Metaphorical Expressions in Translation" by Ghaffar Tajalli (2006) and "Street Talk" by David Burke (1995) were selected as the experimental stimuli the participants had to translate into Persian. A variety of text types which had at least 15 idioms had been exploited as treatment material. The researcher asked two university professors to express their comments on the selected texts and their comments were taken into account in final version of the texts.

\subsection{Procedure}

The students were supposed to translate 10 English texts every session during the semester. Each text was supposed to have around 15 idioms. One week before the treatment session started, the researcher acknowledged that learners could bring their dictionary during treatment sessions. In the first session, an English text as a pretest was 
IJOTL TL, Vol. 4, No. 3, September 2019

p ISSN: 2502 2326; e ISSN: 2502 8278

Https://soloclcs.org; Email: ijolt1@,gmail.com

Center of Language and Cultural Studies, Surakarta, Indonesia

Bazzaz, Edalati Vahid; Niami, Maryam \& Mohammadi, Sharbanoo . 2019. The Impact of Direct and

Indirect Feedback on Idiom Translating Skills of Iranian EFL College Students.

IJOTL TL (2019), 4(3): 129 144. DOI: 10.30957/ijotl-tl.v4i3.605.

given to all participants in order to be sure of their homogeneity and to measure their translation proficiency in use of the idioms. The teacher handed out an English text with an empty writing sheet attached to it and then the participants were told to translate the text individually in less than 15 minutes. Finally, the teacher collected the students' translation. The teacher provided feedback on each student's translation and handed it back to the students in the next lesson. The students were given time to examine the feedback and then translate the next text in the same lesson.

In this study, only the errors related to translation of idioms had been taken into account and the other errors were neglected. The data collection procedures for both groups were the same except for the correction method each group received. In DF group, not only the error translations were identified, but also the participants were provided with a suitable translation of idiom. In other words, the teacher located and gave the correct translation of idiom. In contrast, in IF, the teacher noted the number of error translations of idioms. None of the errors were corrected. To confirm the teacherresearcher's error coding, another colleagues reviewed approximately $60 \%$ of the marked errors in both groups achieving inter-rater agreement at $95 \%$.

The entire study lasted for 10 weeks with one session per week. The post-test started immediately in week 10 after finishing the study to measure the translation proficiency of the participants to see if the treatment had made any difference in skill of idiom translation of the two experimental groups.

\subsection{Coding and Scoring the Translated Texts}

The translated texts were scored using Pica's (1983) Target-Like Use Analysis. The number of accurate translation of idioms was divided by the total number of idioms and finally was multiplied by 100 .

\subsection{Data Analysis}

To obtain quantitative data needed for analysis, the learners' translated texts both in pretest and posttest were coded for statistical analysis. Statistical Package for Social Sciences (SPSS, version 20) was applied to analyze the data. As the data were normal for both groups, an independent samples t-test was used to reveal whether or not two groups were homogenous. Then, paired samples t-test was run for both groups to measure the difference in developing participants' accuracy in translation of idioms between the pretest and posttest of the both groups to see whether treatment had any significant impact on the participants of each group.

\section{RESULTS}

\subsection{The Result of Tests on Direct and Indirect Feedback}

To decide on the statistical procedure to be applied, first it was essential to figure out whether or not the participants' scores in pretest and posttest were distributed normally. With this aim Kolmogorov-Smirnov test was run to confirm the normality of the score distribution and the legitimacy of using parametric tests. An assessment of data normality is a prerequisite for many statistical tests because normal data is an 
IJOTL TL, Vol. 4, No. 3, September 2019

p ISSN: 2502 2326; e ISSN: 2502 8278

Https://soloclcs.org; Email: ijolt1@gmail.com

Center of Language and Cultural Studies, Surakarta, Indonesia

Bazzaz, Edalati Vahid; Niami, Maryam \& Mohammadi, Sharbanoo . 2019. The Impact of Direct and

Indirect Feedback on Idiom Translating Skills of Iranian EFL College Students.

IJOTL TL (2019), 4(3): 129 144. DOI: 10.30957/ijotl-tl.v4i3.605.

underlying assumption in parametric testing. Hence, the main test for the assessment of normality is Kolmogorov-Smirnov test (Steinskog, 2007).

As shown in Table 1, Kolmogorov-Smirnov test demonstrated that values conformed to the non-parametric forms $(\mathrm{p}<0.05)$ in pretest and posttest in both groups.

Table 1 suggests that Kolmogorov-Smirnov test showed that the distribution of the whole sample was significantly normal $(\mathrm{p}>0.05)$. So, parametric tests like pairsamples t-test and independent samples t-test were applied in this section.

Table 1.Test of Normality for Direct and Indirect Feedback

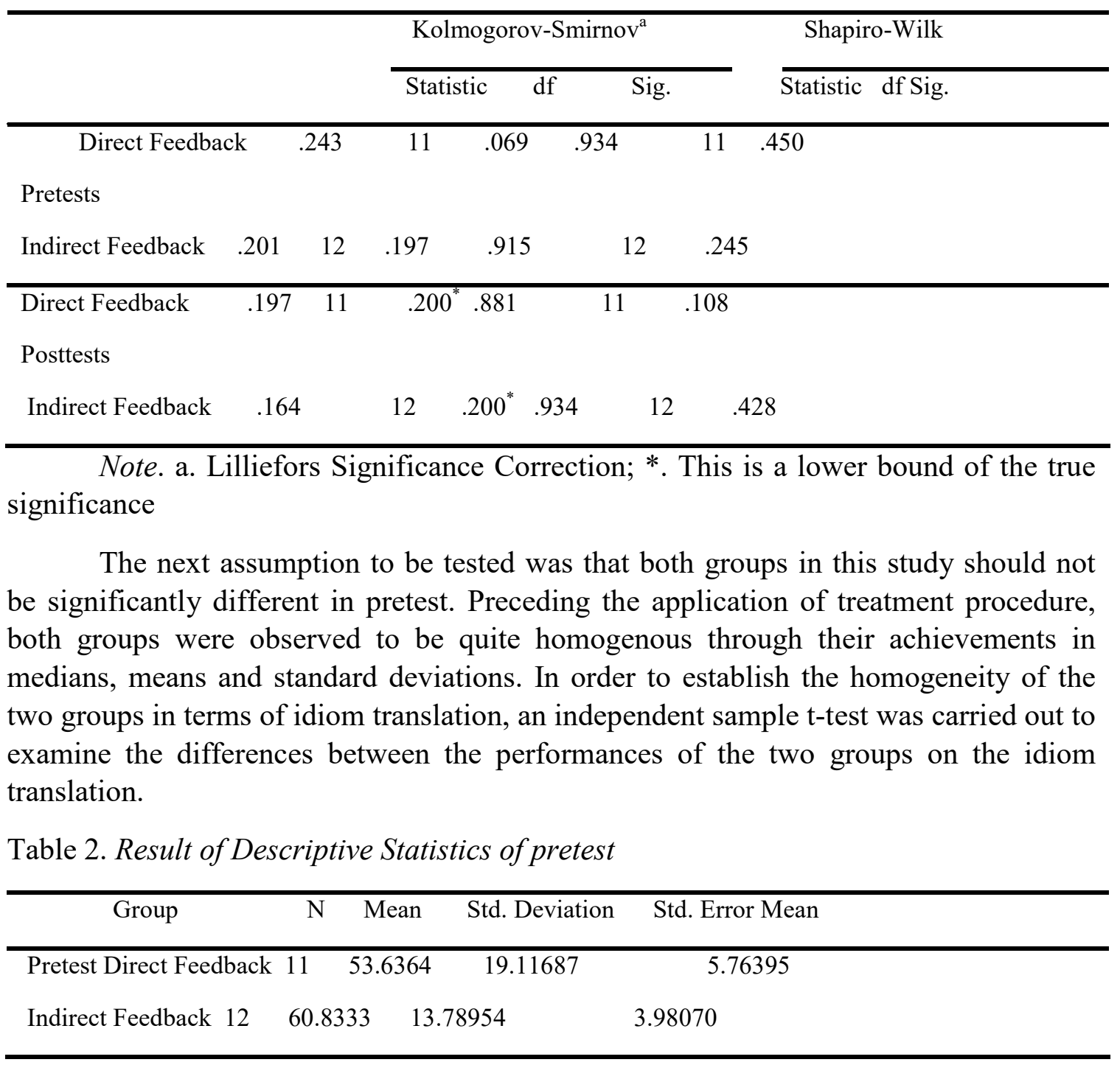


IJOTL TL, Vol. 4, No. 3, September 2019

p ISSN: 2502 2326; e ISSN: 2502 8278

Https://soloclcs.org; Email: ijolt1@gmail.com

Center of Language and Cultural Studies, Surakarta, Indonesia

Bazzaz, Edalati Vahid; Niami, Maryam \& Mohammadi, Sharbanoo . 2019. The Impact of Direct and

Indirect Feedback on Idiom Translating Skills of Iranian EFL College Students.

IJOTL TL (2019), 4(3): 129 144. DOI: 10.30957/ijotl-tl.v4i3.605.

Table 2 presents the descriptive statistics and independent sample t-test analysis of test held as a pretest. As it can be clearly seen, the mean score of the DF group (M= $53.63)$ is lower than the IF group (M=60.83).

Table 3.Result of Independent Sample T-Test in pretest

Levene's Test for

Equality of Variances

\begin{tabular}{ll}
\hline $95 \%$ Confidence \\
& Interval of the \\
& Difference
\end{tabular}

Mean Std. Error

F Sig t df Sig(2-tailed)Difference Difference Lower Upper

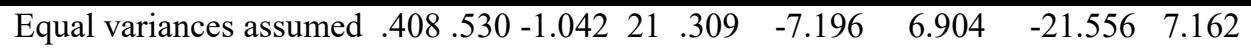

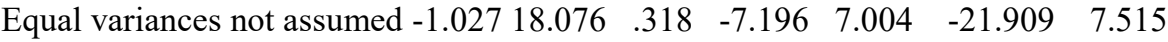

However, the independent sample t-test did not show any significant difference in the mean scores of the direct and indirect feedback groups t (21) $=-1.042, p=.530$; thus, ensured the researchers of the homogeneity of both groups in terms of their translation at the entry level (see Table 3 ).

\subsection{Results for Hypothesis 1}

In order to find the answer to the first research question "Does DF have any significant impact on translating skills of Iranian EFL college students?" a paired samples t-test was used to look at the improvement within DF group. The purpose behind such analysis was to see if the results obtained from the group was the same or not. The descriptive statistics participants' performances on the pretests and posttests were calculated. Table 4 tabulates the descriptive statistics of the group.

Table 4.Results of Descriptive Statistics of Direct Feedback Group on Pretests and Posttests

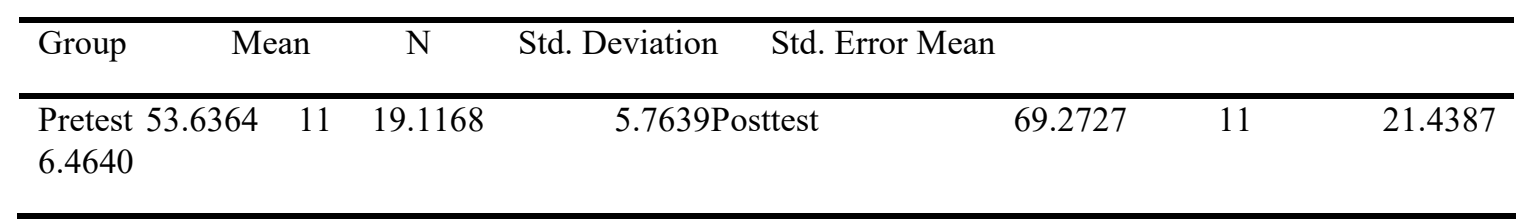


IJOTL $\sim$ TL, Vol. 4, No. 3, September 2019

p ISSN: 2502 2326; e ISSN: 2502 8278

Https://soloclcs.org; Email: ijolt1@gmail.com

Center of Language and Cultural Studies, Surakarta, Indonesia

Bazzaz, Edalati Vahid; Niami, Maryam \& Mohammadi, Sharbanoo . 2019. The Impact of Direct and

Indirect Feedback on Idiom Translating Skills of Iranian EFL College Students.

IJOTL TL (2019), 4(3): 129 144. DOI: 10.30957/ijotl-tl.v4i3.605.

As Table 4 indicates, the mean of DF group increased from the pretest $(M=53.63)$ to the posttest $(M=69.27)$. The observed mean difference was 15.63 , implying that the performance of the DF group had improved significantly.

Table 5.Results of the Paired Samples T-Test of Direct Feedback Group on Pretests and Posttests

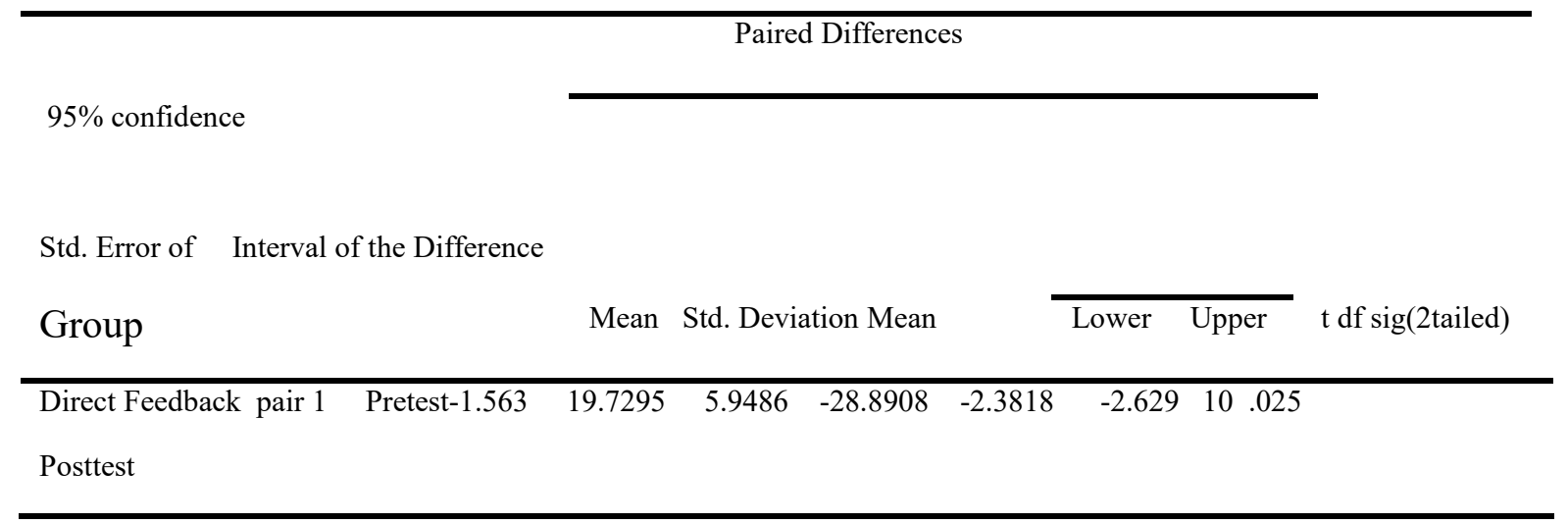

Table 5 presents the results of paired samples t-test to compare the performance of DF group on pretest and posttest. As mentioned above, there was a significant difference between the mean scores on pretest and posttest of the DF group. The result revealed that the learners in the group receiving DF improved significantly in their posttest, $\mathrm{t}(10)=-2.629, \mathrm{p}<.001$. Therefore, the first previously-developed null hypothesis of the study was rejected.

\subsection{Results for Hypothesis 2}

The second research question addressed the issue of whether IF had any significant impact on Iranian EFL learners' translation. A paired samples t-test was conducted to find out whether there was a significant difference in participants' translation achievement before and after the treatment in the group. The descriptive statistics participants' performances on the pretests and posttests of the IF group in translation were calculated. Table 6 tabulates the descriptive statistics of the group.

Table 6.Results of Descriptive Statistics of Indirect Feedback Group on Pretests and Posttests

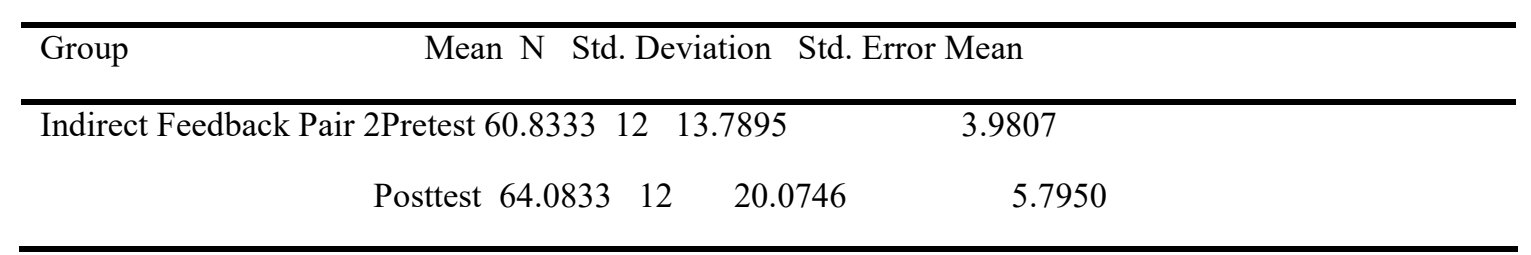


IJOTL $\sim$ TL, Vol. 4, No. 3, September 2019

p ISSN: 2502 2326; e ISSN: 2502 8278

Https://soloclcs.org; Email: ijolt1@gmail.com

Center of Language and Cultural Studies, Surakarta, Indonesia

Bazzaz, Edalati Vahid; Niami, Maryam \& Mohammadi, Sharbanoo . 2019. The Impact of Direct and

Indirect Feedback on Idiom Translating Skills of Iranian EFL College Students. IJOTL TL (2019), 4(3): 129 144. DOI: 10.30957/ijotl-tl.v4i3.605.

As can be observed in Table 6, even though the mean scores of test increased in the group, this rise was trivial from pretest $(M=60.83)$ to posttest $(M=64.08)$. This established the fact that the IF group did not show any significant improvement.

Table 7. Results of the Paired Samples T-Test of Indirect Feedback on Pretests and Posttests

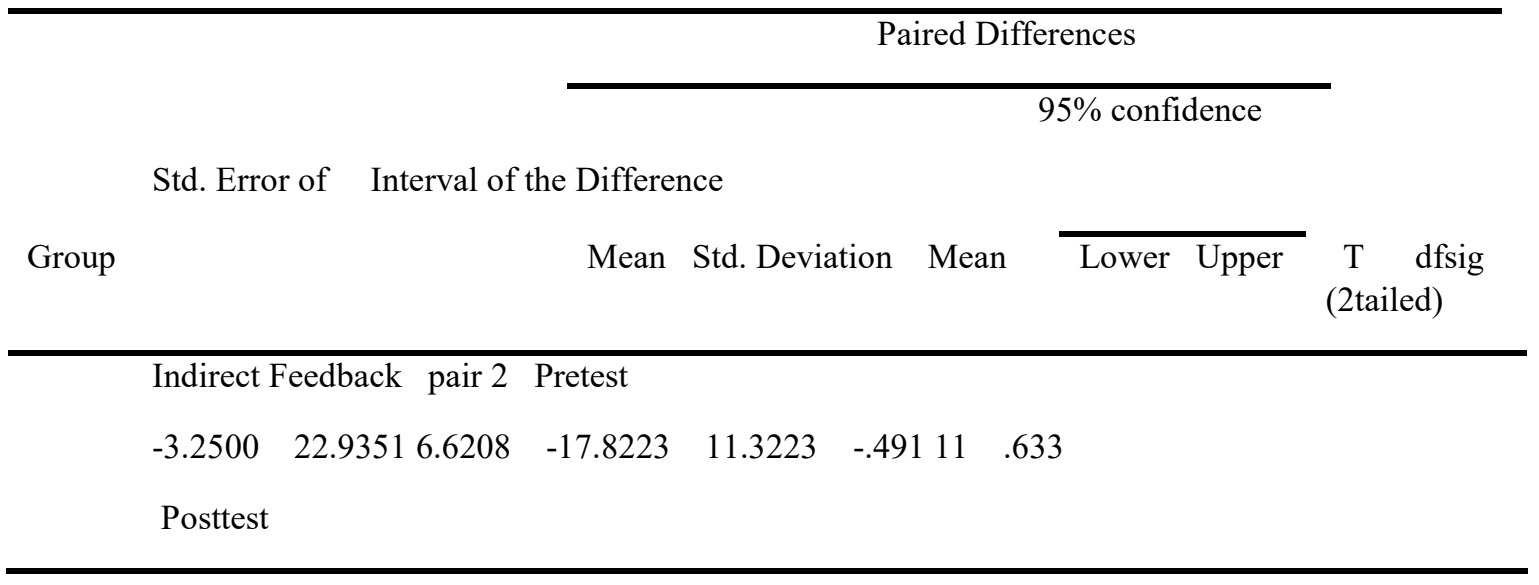

Table 7 displays the results of paired samples t-test to compare the performance of the IF group on the idiom translation pretest and posttest. As explained earlier, there was not a significant difference between the mean scores on pretest and posttest of the IF group. The result revealed that the learners in the class receiving IF did not improve significantly in their posttest for their performance, $t(11)=-.491, p=.633$. . So the null hypothesis, predicting that "Does IF have any significant impact on translating skills of Iranian EFL college students?" was not rejected.

\section{DISCUSSION}

In this section, the researcher is going to begin by discussing the impact of DF on translation of idioms. Later on, the impact of IF on translation of idioms is going to be discussed.

\subsection{The Impact of Direct Feedback on Translation}

The first research question addressed the impact of DF on translating skills of Iranian EFL college students. Learners in group DF showed significant gains in translating idioms accurately, whereas the learners in IF did not.

A large number of investigations are in line with the findings of this part of the study, For instance, Lee's (1997) study has shown that direct prompting of error location was more helpful than indirect prompting and also Ferris (2002) proposed that DF resulted in higher levels of accuracy in education. The mean of DF group increased from pretest to posttest and the students improved significantly. One possible explanation for this 
IJOTL TL, Vol. 4, No. 3, September 2019

p ISSN: 2502 2326; e ISSN: 2502 8278

Https://soloclcs.org; Email: ijolt1@gmail.com

Center of Language and Cultural Studies, Surakarta, Indonesia

Bazzaz, Edalati Vahid; Niami, Maryam \& Mohammadi, Sharbanoo . 2019. The Impact of Direct and

Indirect Feedback on Idiom Translating Skills of Iranian EFL College Students.

IJOTL TL (2019), 4(3): 129 144. DOI: 10.30957/ijotl-tl.v4i3.605.

phenomenon is that when learners do not receive any feedback, they have no opportunity to practice the structure. But when they receive feedback on their errors in each session and the error is located explicitly, they have enough opportunity to practice the wrong part and learn from the feedback; therefore, they improve their translation skill.

Several studies were carried out to prove that DF has more advantages than IF (Ferris \& Roberts, 2001; Ferris, Chaney, Komura, Roberts, \& McKee, 2000; Komura, 1999; Rennie, 2000; Roberts, 1999). One of the advantages of direct corrective feedback is that it provides learners with explicit guidance about how to correct their errors. This is clearly desirable if learners do not know what the correct form is. It means they are not capable of self-correcting the error. The present study found that teacher DF on translated texts resulted in improving accuracy of students' translating on the whole.

According to this study, DF led to better translation of idioms. DF group translated idioms better and noticed the targeted idioms more accurately than IF group and subsequently learned them. As noted by Schmidt (2001) "people learn about the things that they attend to and do not learn much about the things they do not attend to". In terms of DF, it was revealed that our study and Rennie's (2000) had the same results. For each error, having a definite feedback is very important. In other words, translation teachers will function as the commissioner and the translators in training will be the target text producers. The teacher will function as an editor who gives feedback and helps the target- text producers finalize the end product. The result of this study showed the function of students in DF group was better and the mean from pretest to posttest showed the significant progress of students in translating idioms.

\subsection{The Impact of Indirect Feedback on Translation}

The second hypothesis of the research that stated IF does not have any significant impact on translating skills of Iranian EFL college students was confirmed based on the results obtained from this study. This meant that IF had less effect on group B in terms of translation idioms accurately.

Many researchers and scholars believed in using IF, but this study rejected it; maybe because the previous studies were on the other fields of translation. This study was an attempt to investigate the impact of IF on translating idioms. The result and the performance of the participants showed from the scores in pretest to posttest that there was not any outstanding and considerable difference. It can be said that this study is in line with Lee's (2003) idea. Lee (2003) reminds that DF may be appropriate for beginner students or in a situation when teachers want to direct students directly. Therefore, we could conclude despite the results of other researches, this study denies the impact of IF on translation. 
IJOTL TL, Vol. 4, No. 3, September 2019

p ISSN: 2502 2326; e ISSN: 2502 8278

Https://soloclcs.org; Email: ijolt1@gmail.com

Center of Language and Cultural Studies, Surakarta, Indonesia

Bazzaz, Edalati Vahid; Niami, Maryam \& Mohammadi, Sharbanoo . 2019. The Impact of Direct and

Indirect Feedback on Idiom Translating Skills of Iranian EFL College Students. IJOTL TL (2019), 4(3): 129 144. DOI: 10.30957/ijotl-tl.v4i3.605.

Our underlying explanation why in this study IF did not succeed to be more influential in translating might be the nature of this kind of feedback. Baker (1992) believes that "idioms and fixed expressions which contain culture-specific items are not necessarily untranslatable" (p. 68), consequently, IF is not the suitable one to correct the idioms.

Last but not least, the major explanation for the non-significant changes can be that the duration of the investigation was short. Considering that it was difficult to expect immediate improvement in learners' translations, it is debatable that a ten-week treatment time was plainly not long enough to calculate significant changes. Although there were some individual learners who improved significantly in group B, total results did not show the same significant improvement.

\section{CONCLUSION}

This study aimed to provide insight into respective roles of DF as opposed IF on translating idioms. On the whole, the findings and discussion would appear to suggest DF might help learners better than the other kind of feedback to translate the idioms in subsequent translation.

Like many of the studies, the findings of this study add to the bulk of knowledge regarding CF strategies. Perhaps the most salient outcome of this study is that it has shown that a systematic approach to DF can have a positive effect on translating idioms. Hence, teachers should feel confident about providing feedback on students' translated texts. Furthermore, it would be reasonable to allocate some time to the training of teachers in this regard.

The study, however, is not without its limitations. First, the experiment lasted for 12 sessions which was short for this type of experimental study. Second, the present study focused on quantitative assessment. Gathering qualitative data could have provided the opportunity for the researchers to gain more insight into learner's individual feeling about the impact of feedback. Third, Due to the fact that it was very difficult to access a large number of population, this study was conducted with a small number of participants. Forth, the data for this study were taken from a teacher and 23 students at a university in Iran. As a result, the findings of this study could not be applied to all the universities in Iran. And finally, the absence of a true control group, however, constitutes a major limitation in this study. Therefore, future research is needed to address these issues.

\section{REFERENCES}

Aldahesh, A. Y. (2013). On idiomaticity in English and Arabic: A crosslinguistic studyAcademic Journals. Journal of Language and Culture, 4(2), 2329.

Al-Jarrah, R.S. (2016). A suggested model of corrective feedback provision. 
IJOTL $\sim$ TL, Vol. 4, No. 3, September 2019

p ISSN: 2502 2326; e ISSN: 2502 8278

Https://soloclcs.org; Email: ijolt1@gmail.com

Center of Language and Cultural Studies, Surakarta, Indonesia

Bazzaz, Edalati Vahid; Niami, Maryam \& Mohammadi, Sharbanoo . 2019. The Impact of Direct and

Indirect Feedback on Idiom Translating Skills of Iranian EFL College Students.

IJOTL TL (2019), 4(3): 129 144. DOI: 10.30957/ijotl-tl.v4i3.605.

Ampersand, 3, 98107.

Baker, M. (1992).In other words: A course book on translation. London:

Routledge.

Baker, M. (2011).In other words: A course book on translation. London:

Routledge.

Bates, L., Lane, J., \& Lange, E. (1993).Writing clearly: Responding to ESL compositions. Boston: Heinle\&Heinle.

Bitchener, J. (2008). Evidence in support of written corrective feedback. Journal of Second Language Writing, 17, 102-118.

Bitchener, J., Young, S., \& Cameron, D. (2005). The effect of different types of corrective feedback on ESL student writing. Journal of Second Language Writing, 9, 227- 258.

Burke, D. (1995). Street talk 3: The best of American idioms. The US: Optima Books.

Chandler, J. (2003). The efficacy of various error feedbacks for improvement in the accuracy and fluency of L2 student writing. Journal of Second Language Writing, 12, 267- 296.

Cook, P., Fazly, A., Stevenson, S. (2008). The VNC-Tokens Dataset. In Proceedings of the LREC Workshop: Towards a Shared Task for Multiword Expressions (MWE 2008), Marrakech, Morocco, June.

Dollerup, C. (1994) Systematic feedback in translation teaching.In C. Dollerup\& A. Lindegaard (Eds,) Teaching translation and interpreting 2 (pp. 21-132).Amsterdam/Philadelphia: Benjamins.

Ellis, R. (2009). A typology of written corrective feedback types.ELT Journal, 63(2), 97-107.

Farrokhi, F., \&Sattarpour, S. (2012). The effects of direct written corrective feedback on improvement of grammatical accuracy of high-proficient L2 learners. World Journal of Education, 2(2), 49-57.

Ferris, D. R. (1995). Can advanced ESL students be taught to correct their most serious and frequent errors? CATESOL Journal, 8, 41-62.

Ferris, D. R. (1999). The case for grammar correction in L2 writing classes: A response to Truscott (1996). Journal of Second Language Writing, 8(1), 1-10.

Ferris, D. R (2002).Treatment of error in second language student writing. Ann Arbor, MI: The University of Michigan Press.

Ferris, D. R. (2004). The 'grammar correction' debate in L2 writing: Where are we, and where do we go from here? (And what do we do in the meantime...?). Journal of Second Language Writing, 13(1),49-62.

Ferris, D. R. (2006). Does error feedback help student writers? New evidence on the short- and long- term effects of written error correction. In K. Hyland \& Hyland (Eds.), Feedback in second language writing: Contexts and issues (pp. 81-104). New York: Cambridge University Press. 
IJOTL TL, Vol. 4, No. 3, September 2019

p ISSN: 2502 2326; e ISSN: 2502 8278

Https://soloclcs.org; Email: ijolt1@gmail.com

Center of Language and Cultural Studies, Surakarta, Indonesia

Bazzaz, Edalati Vahid; Niami, Maryam \& Mohammadi, Sharbanoo . 2019. The Impact of Direct and

Indirect Feedback on Idiom Translating Skills of Iranian EFL College Students. IJOTL TL (2019), 4(3): 129 144. DOI: 10.30957/ijotl-tl.v4i3.605.

Ferris, D. R., Chaney, S. J., Komura, K., Roberts, B. J., \& McKee, S. (2000).

Perspectives, problems, and practices in treating written error. In Colloquium presented at International TESOL Convention, Vancouver, B.C., March 14-18, 2000.

Ferris, D. R., \&Hedgcock, J. S. (1998). Teaching ESL composition: Purpose, process, and practice. Mahwah, NJ: Lawrence Erlbaum Associates.

Ferris, D., \&m Hedgcock, J. S. (2005).Teaching ESL composition: Purpose, process, and practice. Mahwah, NJ: Lawrence Erlbaum.

Ferris, D., \& Roberts, B. (2001).Error feedback in L2 writing classes. How explicit does it need to be? Journal of Second Language Writing, 10(3), 161184.

Hendrickson, J. (1978). Error correction in foreign language teaching: Recent theory, research and practice. Modern Language Journal, 62, 387-398.

Hendrickson, J. (1980). The treatment of written work.Modern Language Journal, 64, 216-221.

Komura, K. (1999). Student response to error correction in ESL classrooms. Master's thesis, California State University, Sacramento.

Lalande, J.F. (1982). Reducing composition errors: An experiment.Modern Language Journal, 66(2), 140- 9.

Larson, M. L. (1984). Meaning- based Translation: Lanham: University Press of America.

Lee, I. (1997). ESL learners' performance in error correction in writing: Some implications for teaching.System, 25(4), 465- 477.

Lee, I. (2008). Understanding teachers' written feedback practices in Hong Kong secondary classrooms.Journal of Second Language Writing, 17, 69-85.

Lee, S. H. (2003). ESL learners' vocabulary use in writing and the effects of explicit vocabulary instruction. System, 31, 537-561.

Leki, I. (1990). Coaching from the margins: Issues in written response.In B. Kroll (Ed.), Second language writing: Research insights from the classroom (pp. 57- 68). New York: Cambridge University Press.

Longman Idioms Dictionary. 1998. UK: Longman, England.

Makkai, A. (1972). Idiom structure in English. The Hague: Mouton \& Co. N.V.

Pica, T. (1983). Adult acquisition of English as a second language under different conditions of exposure. Language Learning, 33, 465e497.

Polio, C., N. Fleck, \& N. Leder. (1998). "If only I had more time": ESL learners' changes in linguistic accuracy on essay revisions. Journal of Second Language Writing, 7, 43- 68.

Rennie, C. (2000). Error feedback in ESL writing classes: What do students really want? Master's thesis, California State University, Sacramento. 
IJOTL TL, Vol. 4, No. 3, September 2019

p ISSN: 2502 2326; e ISSN: 2502 8278

Https://soloclcs.org; Email: ijolt1@gmail.com

Center of Language and Cultural Studies, Surakarta, Indonesia

Bazzaz, Edalati Vahid; Niami, Maryam \& Mohammadi, Sharbanoo . 2019. The Impact of Direct and

Indirect Feedback on Idiom Translating Skills of Iranian EFL College Students. IJOTL TL (2019), 4(3): 129 144. DOI: 10.30957/ijotl-tl.v4i3.605.

Robb, T., Ross, S., \&Shortreed, I. (1986). Salience of feedback on error and its effect on EFL writing quality. TESOL Quarterly, 20(1), 82-94.

Roberts, B. J. (1999). Can error logs raise more than consciousness? The effects of error logs and grammar feedback on ESL students' final drafts. Master's thesis, California State University, Sacramento.

Schmidt, R. (2001). Attention. In P. Robinson (Ed), Cognition and second language instruction (pp. 3- 32). Cambridge: Cambridge University Press.

Seguinot, C. (1991). A Study of Student Translation Strategies.In S.

Tirkkonen (Ed.), Empirical Studies in Translation and Intercultural Studies, (pp. 79-88). Tubingen: Gunter NarrVerlag.

Sheen, Y. (2007). The effect of focused written corrective feedback and language aptitude on ESL learners' acquisition of articles. Tesol Quarterly, 41, 255-283.

Sheen, Y., Wright, D., \&Moldawa, A. (2009). Differential effects of focused and unfocused written correction on the accurate use of grammatical forms by adult ESL learners. System, 37, 556-569.

Sheppard, K. (1992). Two feedback types: Do they make a difference? RELC Journal, 23, 103-110.

Shikano, M. (2015). The teacher-written feedback in translation education. The Bulletin of the Center for International Education, 16, 1-6.

Shore, S. (2001). Teaching Translation. In E. Steiner \& C. Yallop (Eds) Exploring Translation and Multilingual Text Production: Beyond Content, (pp. 249-276).Berlin: Mouton de Gruyter.

Shreve, G. M. (2002) Knowing Translation: cognitive and experiential aspects of translation expertise from the perspective of expertise studies. In A. Riccardi (Ed.), Translation Studies. Perspectives on an Emerging Discipline, (pp. 150-71). Cambridge: Cambridge University Press.

Steinskog, DJ. (2007). A cautionary note on the use of the KolmogorovSmirnov test for normality. American Meteor Soc. 135:115 1-7.

Storch, N. \& Wiglesworth, G. (2010a). Learners' processing, uptake, and retention of corrective feedback on writing. Studies in Second Language Acquisition, 32, 303- 334.

Storch, N. \& Wigglesworth, G. (2010b). Students' engagement with feedback on writing: the role of learner agency/ beliefs. In R. Batstone (Ed.), Sociocognitive perspectives on language use and language learning, (pp. 166185). Oxford, United Kingdom: Oxford University Press.

Tajalli, G. (2006). Idioms and metaphorical expressions in translation, Tehran: SAMT.

Trrefry, D. (2006). Collins English Dictionary. Glasgow, UK: HarperCollins Publishers. 
IJOTL TL, Vol. 4, No. 3, September 2019

p ISSN: 2502 2326; e ISSN: 2502 8278

Https://soloclcs.org; Email: ijolt1@gmail.com

Center of Language and Cultural Studies, Surakarta, Indonesia

Bazzaz, Edalati Vahid; Niami, Maryam \& Mohammadi, Sharbanoo . 2019. The Impact of Direct and Indirect Feedback on Idiom Translating Skills of Iranian EFL College Students. IJOTL TL (2019), 4(3): 129 144. DOI: 10.30957/ijotl-tl.v4i3.605.

Truscott, J. (1996). The case against grammar correction in L2 writing classes. Language Learning, 46, 327-369.

Truscott, J. (2007). The effect of error correction on learners' ability to write accurately. Journal of Second Language Writing, 16, 255-272.

Van Beuningen, C., De Jong, N., \& Kuiken, F. (2008). The effect of direct and indirect corrective feedback on L2 learners' written accuracy. ITL International Journal of Applied Linguistics 156, 279-296.

Van Beuningen, C., De Jong, N., \&Kuiken, F. (2012). Evidence on the effectiveness of comprehensive error correction in second language writing. Language Learning, 62 (1), 1-41.

Steendam, E. V.,Rijlaarsdam,G. C. W., Van den Bergh, H. H., Sercu, L.(2014).The mediating effect of instruction on pair composition in L2 revision and writing. In Instructional Science, 42, 905-927.

Walz, J. C. (1982). Error correction technique for the foreign language classroom. Language in education: Theory and Practice Series. Washington DC: Centre for Applied Linguistics. 